[word count: 6,996 - minus cover page and abstract]

\title{
Female Party Attachment in a Power Sharing Polity: The Erosion of Protestant Support in Northern Ireland
}

\author{
Bernadette C. Hayes \\ Institute for Conflict, Transition, and Peace Research \\ School of Social Sciences \\ University of Aberdeen \\ Aberdeen AB24 3QY \\ Scotland \\ and \\ Joanne McEvoy \\ Department of Politics and International Relations \\ School of Social Sciences \\ University of Aberdeen \\ Aberdeen AB24 3QY \\ Scotland
}

Direct all correspondence to:

Bernadette C. Hayes

Institute for Conflict, Transition, and Peace Research

School of Social Science

University of Aberdeen

Aberdeen AB24 3QY

Scotland

Phone: 00-44-1224-273128

Email: b.hayes@abdn.ac.uk 


\title{
Female Party Attachment in a Power Sharing Polity: The Erosion of Protestant Support in Northern Ireland
}

\begin{abstract}
Power sharing hinges on cooperation between communal parties who are expected to mobilise citizens in support of the new political system. Yet, women are often illserved and their political differences exacerbated by such arrangements. Mindful of this finding and using data from the 2015 Northern Ireland Election Survey, we examine differences in party attachment between Catholic and Protestant women. The results suggest that Catholic women are more likely to claim a party attachment than Protestant women and a key factor in accounting for this phenomenon is differences in their levels of endorsement and perceived effectiveness of the two main political parties.
\end{abstract}

\section{Introduction}

International peace negotiators, academics and policymakers increasingly accept that the design and implementation of political arrangements involving the main antagonists to the conflict is the most viable approach to resolving inter-communal division in societies emerging from deep-seated ethnic conflict. Internal power-sharing arrangements among political elites along communal lines has become the dominant approach to resolving inter-communal strife in post-conflict societies. In principle, this form of government, otherwise known as the consociational approach ${ }^{1}$ is seen as enabling communities that have conflicting identities based on ethnic differences to ameliorate and eventually remedy these long-standing patterns of division and to coexist in a politically stable, peaceful and inclusive society. By recognising the salience of ethnic divisions and by providing groups access to power on a proportional basis, supporters of consociationalism argue that not only will communal elites be incentivised to cooperate but also to bring their constituents with them in a spirit of accommodation and compromise. ${ }^{2}$ Political parties are central to this process. For effective and stable power sharing, communal parties must cooperate with one another and encourage their constituents to support the political system. In doing so, not only do political parties help legitimate the new political arrangements but they also promote 
peaceful inter-communal relations. ${ }^{3}$

The importance of political parties in deeply divided societies to resolving conflict is further underpinned by the ethnic party system. ${ }^{4}$ In such societies, not only do political parties remain highly segregated along ethnic lines but ethnic outbidding whereby parties within the same ethnonational bloc seek to portray themselves as the true defenders of their own ethnic group - accompanied by ethnic tribal voting is often the primary, if not sole, mechanism for party competition. ${ }^{5}$ In fact, more so than any other factor, it is this issue, or the ability of such parties to act as ethnic tribunes under well-designed power sharing, that advocates of consociationalism suggest allows formerly hard-line ethnic parties to moderate their political stance and adopt a more conciliatory approach to issues beyond the ethnonational question. As Mitchell et al put it: 'With appropriate power-sharing institutions ethnic parties derive electoral rewards by competing on more moderate platforms, providing that they reinforce an "ethnic tribune appeal", i.e. the perception that they most effectively represent their groups' ethnonational interests. ${ }^{6}$

Not all political analysts, however, share this view. Some scholars point to the negative effects of the consociational model, notably its tendency to freeze communal division and political representation along ethnonational lines. Moreover, as the electoral success of parties in this instances are dependent on exclusive appeals to ethnic loyalties rather than on issues of class or ideology, the representation of the interests of citizens outside these forms of allegiances, including the political rights of women, are either ignored or considered secondary to the ethnonational question at best. ${ }^{7}$ Feminist scholars, in particular, have been highly critical of consociational power sharing, pointing not only to the systematic marginalisation of women and their collective interests but also to the reproduction of patriarchal privilege in consociational institutions and their power-sharing practices. ${ }^{8}$ Even feminist scholars who are less critical of such power sharing acknowledge that women and their interests are ill-served by such political arrangements. As Byrne and McCulloch put it: '[While] there is nothing inherent in power-sharing that cannot be made more democratic and inclusive of women....the failure to theorise gender and recognize gender power relations means that women remain invisible in the literature's prescription for conflict resolution and 
in power-sharing practices. $^{9}$

It is with these various findings in mind that this study focuses on differences in party attachment among women. Despite the importance of political parties for the stability of power-sharing arrangements as well as their suggested marginalisation of the collective interests of women in societies emerging from conflict, to date, the position of women in relation to party attachment has received little scholarly attachment. This is particularly the case when differences in the degree of attachment among women to ethnic parties is considered. ${ }^{10}$ The absence of such research must be considered surprising for the following two reasons.

First, it is increasingly recognised that the political contribution of women is vital for the successful and peaceful transition of societies emerging from conflict. A view it should be noted that has been repeatedly endorsed by the United Nations Security Council in a series of resolutions on Women and Peace and Security. ${ }^{11}$ Second, as proponents of intersectionality correctly point out, women do not form a politically monolithic group. Previous research has shown that not only are women divided by the range of factors - such as class, age, race and religion - in terms of their electoral turnout and party preferences in established democracies, ${ }^{12}$ but this is also the case in many post-conflict societies where women are often sharply differentiated both by long-standing ethnic or religious loyalties as well as unequal access to resources. ${ }^{13}$ It is with this specific finding in mind - intersectionality or long-standing political divisions among women - that this investigation focuses on differences between Protestant and Catholic women in terms of their party attachments. The article proceeds in two stages. First, it outlines the relationship between the 1998 Agreement and the nature of party representation and support for the political advancement of women in Northern Ireland. Building on this analytical discussion and using nationally representative data from the 2015 Northern Ireland General Election Survey, ${ }^{14}$ it then examines religious differences in party attachment among women. 


\section{Women, Political Parties and the Northern Ireland Agreement}

Signed in April 1998, the Northern Ireland Agreement is an example of elite intervention to resolve ethnic conflict. Based on a consociational model of governance and 'parity of esteem' between unionists and nationalists, a key assumption of the Agreement was that entrenched ethnonational divisions could be accommodated and eventually ameliorated through power-sharing arrangements. These arrangements included: the formation of a Northern Ireland Assembly with devolved legislative powers; the creation of a power-sharing Northern Ireland Executive, headed by a premiership diarchy and with ministers allocated proportionately to the main parties; and the introduction of mutual vetoes, or the principle of cross-community approval for major decisions taken by the Assembly. ${ }^{15}$ More so than any other issue, critics of the consociational power-sharing arrangements argue that it is this factor - the legislative requirement of cross-community support for major decisions - which not only legitimises ethnonational division and exacerbates conflict but has also resulted in increasing support for the political extremes, including the carve up of electoral politics along communal lines. ${ }^{16}$

Recent research on Northern Ireland, however, calls into question the assumption that ethnic outbidding inevitably leads to ethnic polarisation and heightened division. There is now widespread agreement that ethnic outbidding has been the driving force of party competition since the Agreement. More specifically, not only have the traditionally more 'extreme' parties, the Democratic Unionist Party (DUP) and Sinn Féin (SF), risen in ascendancy at the expense of their earlier more successful moderate counterparts the UUP and SDLP - but they now account for over two-thirds of the vote share within their respective unionist and nationalist blocs. ${ }^{17}$ This growth in support within their respective ethnonational communities has been accompanied by a significantly more moderate stance and an increasing inter-ethnic convergence in attitudes beyond the constitutional question, such as support for power-sharing and the Northern Ireland Assembly. ${ }^{18}$ A view, or pro-power sharing position, it should be noted that is now also increasing in line with the opinions of their medium voter.

According to this perspective, intra-party competition and electoral support in Northern Ireland no longer revolves around the position of the parties in relation to 
power sharing or support for the Northern Ireland Assembly (issue based) but are now based on public perceptions concerning the effectiveness of parties (valence), or their capacity to act as ethnic tribune parties in representing the interests of their community. ${ }^{19}$ There is also evidence to suggest that since 2007, when the DUP and SF agreed to share power, not only has a period of growing stability taken hold but one in which 'bread and butter' issues and, more recently, even moral issues such as gay marriage have begun to dominate the political agenda. ${ }^{20}$ This growth in relative moderation, however, is not to discount continuing marked divisions between the parties, particularly in relation to how to come to terms with the legacy of Northern Ireland's violent past, ${ }^{21}$ as well as more recent disagreements over a bungled energy scheme which led to the resignation of Martin McGuinness and the subsequent collapse of the Assembly in January 2017. ${ }^{22}$

While there is considerable evidence to suggest that Northern Ireland party politics in the post-accord period has undergone an important transformation, such as the rise in ascendancy albeit of a much more moderate DUP and SF, this transformation has not been accompanied by the political advancement of women. As Brown and Ni Aolain write: 'While a shift...to a more moderate form of government by "ethnic tribunes" has been detected... NI's post-settlement realities evidence sustained functional weakness underpinned by a healthy dose of misogynous masculinity., 23 Despite a separate clause in the Agreement which committed the political parties to formally recognise the right of women to 'full and equal political participation', the political arena has remained a 'cold house' for women. ${ }^{24}$

Even the establishment and subsequent electoral success of the Northern Ireland Women's Coalition (NIWC) - a women's cross-community party, consciously not organised around ethnonational concerns - in the post-accord period was an extremely short-lived affair. Undercut by the consociational power-sharing arrangements and the electoral victories of the DUP and SF, not only did its two representatives fail to be re-elected in the 2003 Northern Ireland Assembly elections but the party was disbanded in 2006. Moreover, while there has been a number of attempts to unite female Assembly members (MLAs) via a cross-party women's caucus - the most recent occurred with the launch of the Assembly's Women Caucus in March 2016 - the primacy of party position and communal identity continues to 
undermine such initiatives. Even on key gendered concerns, such as gay marriage and female reproductive rights, veto mechanisms, such as the legislative requirement of cross-community support, have increasingly been used, particularly by the DUP, to cement inter-communal party division and stymie any progress. ${ }^{25}$

There is also evidence to suggest that some of the main political parties, particularly the DUP, have demonstrated a widespread lack of interest in the promotion of women in the political arena. ${ }^{26}$ For example, Braniff and Whiting in their study of DUP party members found no generational shift in opinion regarding the promotion of female political participation and an overall negative view of positive discrimination persists. ${ }^{27}$ Despite the recent increase in the number of women elected to the Northern Ireland Assembly after the 2016 election, ${ }^{28}$ female political representation continues to significantly lag behind that of their female counterparts in Scotland and Wales and is still the lowest in Western Europe for comparable devolved institutions. Moreover, in comparison to their male counterparts, political apathy remains widespread among women as does their greater lack of support for the new political arrangements. This is particularly the case when women within the unionist community are considered. ${ }^{29}$ As Galligan notes, despite the Agreement heralding a new beginning in terms of gender equality and the advancement of women, 'the promise of women's full and equal political participation remains largely unfulfilled. 30

\section{Women and Party Attachment}

Previous research suggests that the political arena in the post-Agreement period in Northern Ireland has proved to be an inhospitable place for women. Despite the promised commitment to gender equality and the advancement of the rights of women, there is evidence to suggest increasingly female disillusionment with the political institutions, particularly within the unionist community. To what extent is this also the case when levels of political attachment are considered?

Table 1 addressed this question using data from the 2015 Northern Ireland Election Survey. The results show that although only a minority of women in both communities claimed a party attachment, Protestant women were less likely to do so 
than Catholic women. While just two-fifths of Protestant women claimed to have a party identification, 46 per cent of Catholic women shared this view. ${ }^{31}$ Even more so among the politically uncommitted, it is again Protestant women who stand out as the most detached in their views; whereas just under half of Protestant women who did not have a party identification also stated that they were not close to a political party, the equivalent proportion among Catholic women was notably lower at just 38 per cent. ${ }^{32}$ Moreover, there is some evidence to suggest that this greater party attachment among Catholic women is a relatively recent phenomenon, which has fluctuated somewhat since the turn of the century.

\section{[Insert Table 1 about here]}

As the data in Table 2 demonstrates, while party attachment was higher among Protestant women than Catholic women in 1998 - 46 per cent as compared to 42 per cent claimed a party attachment - by 2001, a marginally higher proportion of Catholic women than Protestant women - 38 per cent as compared to 37 per cent women expressed this view. Although levels of party attachment among Protestant women again outstripped that of Catholic women by a margin of eight percentage points in 2005 - 42 per cent versus 50 per cent - by 2010, or three years after the restoration of the Assembly in which the DUP and SF agreed to share power, this pattern had again been reversed. Despite a dramatic fall in party support among women particularly in the unionist Protestant community, at 34 per cent and 28 per cent respectively, party attachment was again higher among Catholic women that Protestant women. And, while party attachment has rebounded somewhat among women since then, with an increase of 12 percentage points in both religious communities by 2015, Catholic women still remain more likely to claim a party attachment than Protestant women.

[Insert Table 2 about here]

\section{Religious Differences in Party Support}

There are a number of possible explanations as to why party attachment is now lower among Protestant women compared to their Catholic counterparts, the most obvious being their greater antipathy towards the two main political parties, particularly in terms of their perceived effectiveness in representing the interests of their own 
community. As noted earlier, it is this factor - judgements concerning the effectiveness of both the DUP and SF in standing up for their ethnic community - which supporters of the ethnic tribune thesis suggest accounts for their dramatic success at the ballot box since the turn of the century. To what extent is this also the case when party attachment among women is considered? Are there religious differences between women in relation to this issue?

The results in Table 3 are clear. Irrespective of whether a personal endorsement of the two main political parties or their perceived effectiveness in representing their respective communities are considered, it is Protestant women who stand out as the most negative in their views. For example, although a clear majority of women -63 per cent in this instance - claimed to 'like' the DUP and SF, at 61 per cent and 66 per cent respectively, Protestant women were somewhat less likely to do so than Catholic women. A similar pattern emerges when views on each of the parties within their own communities are considered; whereas 61 per cent of Protestant women said that they liked the DUP, the equivalent level of endorsement among Catholic women for SF was again somewhat higher at 65 per cent. ${ }^{33}$ It is interesting to note, however, crosscommunity party endorsement is almost minuscule in this instance; while only four per cent of Protestant women said that they liked SF, the per cent of Catholic women who expressed a similar view in relation to the DUP was even lower at just two per cent.

[Insert Table 3 about here]

These findings are replicated when judgements concerning the effectiveness of the two main parties in representing the interests of their respective communities are considered, although cross-community affirmation is significantly higher in this instance. While the overwhelming majority of women -72 per cent - viewed either the DUP or SF as an effective voice for their respective communities, only 68 per cent of Protestant women as compared to 78 per cent of Catholic women endorsed this position. A more pronounced pattern emerges when perceptions of the effectiveness of each of the parties within their own communities are considered; while just 52 per cent of Protestant women judged the DUP as an effective voice for unionism, the percentage of Catholic women who perceived SF as the pre-eminent voice of nationalism was markedly higher at 70 per cent. ${ }^{35}$ It is interesting to note, however, when cross- 
community perceptions in terms of party effectiveness are considered both Protestant and Catholic women are almost equally divided in their views. This is not discount, however, the perceived greater overall effectiveness of SF in relation to this issue; while just over half of both Catholic and Protestant women endorsed the DUP as the most effective voice for their own community, the equivalent percentage among those who held an identical view about SF was nearly 10 percentage points higher at 61 per cent.

There is also some evidence to suggest that this perceived lack of effectiveness of the DUP, particularly among Protestant women, has remained relatively stable over time. As the data in Table 4 demonstrates, although judgements about the effectiveness of both the DUP and SF have risen among women in both religious communities, it is particularly marked among Catholic women. For example, while reported effectiveness of both the DUP and SF among Catholic women has increased by 16 percentage points - from 62 per cent to 78 per cent - since the last Westminster election in 2010, the equivalent rise among Protestant women - from 63 per cent to 68 per cent - was just five percentage points. This pattern is replicated when each of the political parties are considered separately. Again, while judgements about party effectiveness ratings concerning SF and particularly the DUP have risen sharply among Catholic women resulting in gains of 11 and 24 percentage points, respectively - they have experience only a moderate increase -3 per cent and 6 per cent - among Protestant women.

\section{[Insert Table 4 about here]}

In summary, the results are clear. Irrespective of whether attitudes to the two main political parties - the DUP and SF - or their perceived effectiveness in representing the interests of their respective unionist and nationalist communities are considered, it is Protestant women who stand out as the least positive in their views. This is particularly the case when the effectiveness of parties is considered. At just 52 per cent, not only do a bare majority of Protestant women endorse the DUP as the most effective party to 'stand up' for unionism but there is also evidence to suggest that this lack of endorsement has remained relatively stable overtime. 


\section{The Net Effect of Religion and Party Support on Party Attachment}

To what extent can these differing levels in party support account for the religious differences in party attachment among women? In other words, is it differences in their support for the two main political parties, both in terms of their level of personal endorsement and judgements concerning their effectiveness, which accounts for the lesser levels of party attachment among Protestant women? To address this question, Table 5 presents the results of three regression models: Model 1 which shows the effect of religion on female party attachment; Model 2 which shows the estimate for religion, once controls for socio-economic background and national identity are included in the regression equation; and Model 3 which shows the religion effect once the influence of attitudes towards the two main political parties - the DUP and SF - are also taken into account. The figures in each model are the parameter estimates, while the standard errors for each of the estimations are shown in parentheses.

The results support our hypothesis that it is differences in support for the two main political parties - DUP and SF - that accounts for the religious gap in partisanship among women. As the data in Table 5 shows, although religion has an independent and statistical significant effect on party attachment (Model 1), an effect that remains when a range of control variables, such as socio-economic background and national identity, are included in the regression equation (Model 2), this statistical difference no longer holds when party support is added to the investigation (Model 3).

\section{[Insert Table 5 about here]}

Focusing initially on Model 1, the results are conclusive. Religion is a statistically significant determinant of partisanship. More specifically, Catholic women are notably more likely to claim to be a supporter of a political party than Protestant women. An identical result emerges when a range of control variables, including national identity, are added to the regression equation (Model 2). Religion is again a significant net predictor of partisanship; Catholic women are significantly more likely to claim a party attachment than Protestant women. In fact, with the notable exception 
of age - older women are more likely to claim a party attachment than younger women - religion is the sole predictor of partisanship in this instance.

This is not the case, however, when the influence of attitudes towards the two main political parties - the DUP and SF - are added to the equation. As the results in Model 3 indicate clearly, religion is no longer a significant predictor of party attachment in this instance. The key net predictors of partisanship are both a personal endorsement of the two main political parties as well as judgements about their effectiveness. More specifically, women who 'liked' the two main political parties and viewed them as an 'effective voice' for their respective communities were notably more likely to claim a party attachment than those who did not. With the notable exception of age, attitudes towards the two main political parties are the sole predictors of partisanship in this instance. Thus, at least as far as religious differences in partisanship among women in Northern Ireland are concerned, it is this factor - the extent to which they are willing to personally endorse the two main political parties and perceptions concerning their effectiveness - which explains the religious gap in party attachment.

\section{Electoral Outcomes}

A key element in accounting for the electoral success of both the DUP and SF is perceptions concerning their effectiveness in representing the interests of their own community. More so than any other issue, it is this factor-judgements concerning their effectiveness in standing up for their own ethnic communities - which supporters of the ethnic tribune thesis suggest accounts for their ascendancy at the ballot box. To what extent is this also the case when electoral support among women is considered? Detailed analysis is difficult because of the relatively small numbers of survey respondents involved, but the results suggest that not only was electoral turnout much higher among effective female voters - those who endorsed the DUP or SF as the most effective voice for their respective community - but they were also overwhelming more likely to cast their vote for the main party within their own ethnonational bloc.

As the data in Table 6 shows, while two-thirds of Protestant women who judged the DUP to be the most effective party to represent their community turned out to vote, the vast majority of them -83 per cent - also voted for the DUP as their preferred party 
of choice. By contrast, among non-effective female Protestant voters - those who did not endorse the DUP as the most effective voice for unionism - electoral turnout was not only markedly lower - 44 per cent - but their preferred party of choice was the UUP.

[Insert Table 6 about here]

An identical pattern emerges when the link between party effectiveness and electoral behaviour within the female Catholic community is considered. As the data in Table 6 also show, while four-fifths of Catholic women who judged SF to be the most effective party to represent their community turned out to vote, the vast majority of them - 75 per cent - also cast their vote for SF as their preferred party of choice. By contrast, among non-effective female Catholic voters electoral turnout was not only markedly lower - 54 per cent - but for a notable majority - 62 per cent - their party of choice was the SDLP. While the evidence is not conclusive, given the relatively small numbers involved, it does suggest support for the ethnic tribune thesis, namely the link between party effectiveness, electoral turnout, and vote choice within the female voting population in both religious communities.

\section{Conclusion}

Power-sharing stability depends on the capacity of communal parties to cooperate in government on the basis of solid electoral support. In deeply divided societies transitioning to power sharing, stability hinges on the ability of parties to represent their constituents. Yet, in such societies, not only do political parties remain highly segregated along ethnic lines but 'ethnic outbidding' and 'ethnic delivery' is often the primary, if not sole, instrument of voter mobilisation and party choice. Despite an increasing recognition as to the importance of the inclusion of women for the long-term stability of societies emerging from conflict, appeals to citizens along ethnic and/or religious lines have dominated party political agendas. This is particularly the case among parties involved in consociational forms of power-sharing arrangements, where efforts to represent or appeal to the political interests of women are considered irrelevant or marginal at best. 
The results of this investigation lend further support to the view of women's disengagement from party politics in power-sharing systems. First, irrespective of whether the Protestant or Catholic community is considered, party attachment remains quite low among women. Currently, only a minority of women in both religious communities claim a party identification. Second, there is also evidence to suggest a religious gap in party attachment among women. Female members of the Protestant community are somewhat less likely to claim a party attachment than their Catholic counterparts and this is particularly the case when the most politically uncommitted are considered. Third, our results point to the importance of attitudes towards the two main parties - both in terms of their level of personal endorsement and judgements concerning their effectiveness - in accounting for the religious gap in party attachment among women. More so than any other issue, it is the greater antipathy among Protestant women towards the DUP, particularly in terms of its perceived effectiveness to represent the interests of the unionist community, which explains their lower rates of party attachment.

What may account for these findings? One possible explanation is the differing responses of the parties to the political role of women. As noted earlier, although ethnic outbidding among the two main parties has now become the dominant form of party competition in Northern Ireland, not only do both Protestant and Catholic women perceive SF as the most effective party in 'standing up' for their own community, but of the two main parties it has also been the most proactive in promoting gender policies, particularly the representation of women. It is this factor, the greater marginalisation and lack of female political representation within the unionist community, which we suggest is a key contributing element in explaining the greater political disillusionment among Protestant women in this instance.

The results have a number of implications for power-sharing theory and practice. First, scholarship on power sharing must address the link between representation and party attachment, particularly as it relates to differences between women. As the results of this investigation show, women are not a homogeneous group. Moreover, the degree to which parties and their leaders benefit from the support of women is neither uniform nor gender neutral. It is to this issue - the different experiences and long-standing divisions among women under power-sharing 
arrangements - that future scholarship should be directed. While much recent scholarly attention has focused on the gendered effects of power-sharing, namely the greater marginalisation of women as compared to that of men, the differing experiences of women under such power-sharing arrangements has all but been ignored.

Second, both political parties and their leaders would do well to pay attention to the concerns of their female constituents. This is particularly so in ethnically divided societies based on liberal consociation, where success in elections, and not pre-determined quotas, decide the number of seats that parties are entitled to in government. As the results of this investigation also demonstrate, by focusing explicitly on the interests of women, not only will parties and their leaders maximise support within their own ethnic blocs but they will also reap the benefits of such an approach at the ballot box and in government.

Finally, greater attention should also be paid to the role of parties and leaders in strengthening the political attachment and engagement of women. As the results of this investigation also show, political elites play a vital role in the mobilisation of their constituents. While much attention has been paid to the strategies used by parties and their political leaders in appealing to voters along ethnonational lines, their ability and willingness to target and represent the collective interests and democratic representation of women have, by comparison, been much neglected.

\section{Acknowledgements}

This study was funded by the Economic and Social Research Council (Award: ES/L007320/1). 


\section{Notes}

1. Lijphart, Arend. 1977. Democracy in Plural Societies. New Haven: Yale University Press; Lijphart, Arend. 2004. "Consociational Design for Divided Societies." Journal of Democracy. 15(2): 96-101; McGarry, John and Brendan O'Leary. 2004. The Northern Ireland Conflict: Consociational Engagements. Oxford: Oxford University Press.

2. Lijphart, Democracy in Plural Societies.

3. Diamond, Larry. 1977. 'Introduction: In Search of Consolidation.' In Larry Diamond, Marc E. Platter, Yun-han Chu and Hung-mao Tien (eds.), Consolidating the Third Wave Democracies: Regional Challenges. Baltimore: Johns Hopkins University Press, pp xiii-xlvii; Lipset, Seymour Martin. 2000. 'The Indispensability of Political Parties.' Journal of Democracy. 11(1): 48-55; Manning, Carrie. 2008. The Making of Democrats: Elections and Party Development in Postwar Bosnia, El Salvador, and Mozambique. Basingstoke: Palgrave Macmillan; Reilly, Benjamin. 2003. 'Political Parties and Post-Conflict Peacebuilding.' Civil Wars. 15(81): 88-104.

4. Horowitz, Donald. 1985. Ethnic Groups in Conflict. Berkeley: University of California Press; Reilly, Benjamin. 2006. 'Political Engineering and Party Politics in Conflict-Prone Societies.' Democratization. 13(5): 811-827.

5. Rabushka, Alvin and Kenneth A. Shepsle. 1972. Politics in Plural Societies. Columbus OH: Charles E. Merrill; Horowitz, Ethnic Groups in Conflict; Reilly, 'Political Engineering and Party Politics.'; Mitchell, Paul and Geoffrey Evans. 2009. 'Ethnic Party Competition and the Dynamics of Power Sharing in Northern Ireland.' In Rupert Taylor (ed.), Consociational Theory: McGarry and O'Leary and the Northern Ireland Problem. London: Routledge, pp. 146-164.

6. Mitchell, Paul, Evans, Geoffrey and Brendan O'Leary. 2009. 'Extremist Outbidding in Ethnic Party Systems is Not Inevitable: Tribune Parties in Northern Ireland.' Political Studies. 47: 397-421, p. 41.

7. Galligan, Yvonne. 2006. 'Women in Northern Ireland's Politics: Feminising an Armed Patriarchy.' In Mariam Sawer, Manon Tremblay and Linda Trimble (eds.), 
Representing Women in Parliament. London: Routledge, pp. 204-220; Byrne, Siobhan and Allison McCulloch. 2012. 'Gender, Representation and Power-Sharing in PostConflict Institutions.' International Peacekeeping. 19(5): 565-580; Hayes, Bernadette C. and Ian McAllister. 2012. 'Gender and Consociational Power-Sharing in Northern Ireland.' International Political Science Review. 34(2): 123-139; Galligan, Yvonne. 2013. 'Gender and Politics in Northern Ireland: The Representation Gap Revisited.' Irish Political Studies. 28(3): 413-433; Hayes, Bernadette C. 2017. 'Religious Differences in Electoral Turnout among Women in Northern Ireland.' Parliamentary Affairs. 70: 322-343. Kennedy, Ronan, Pierson, Claire and Jennifer Thomson. 2016. 'Challenging Identity Hierarchies: Gender and Consociational Power-Sharing.' British Journal of Politics and International Relations. 18(3): 618-633.

8. Galligan, 'Women in Northern Ireland's Politics.'; Brown, Kris and Fionnuala Ni Aolain. 2015. 'Through the Looking Glass: Transitional Justice Futures through the Lens of Nationalism, Feminism and Transformative Change.' International Journal of Transitional Justice. 9(1): 127-149, p. 134.

9. Byrne and McCulloch, 'Gender, Representation and Power-Sharing.' pp. 566, 568.

10. Htun, Marla. 2004. 'Is Gender Like Ethnicity? The Political Representation of Identity Groups.' Perspectives on Politics. 2(3): 439-458; Holmsten, Stephanie S., Moser Robert G. and Mary C. Slosar. 2010. 'Do Ethnic Parties Exclude Women?' Comparative Political Studies. 43(10): 1179-1201; Waylen, Georgina. 2010. Engendering Transitions: Women's Mobilization, Institutions and Gender Outcomes. Oxford: Oxford University Press.

11. Byrne and McCulloch, 'Gender, Representation and Power-Sharing.' pp. $566,568$.

12. Huddy, Leonie, Cassese, Erin and Mary-Kate Lizotte. 2008. 'Sources of Political Unity and Disunity Among Women.' In Lois Duke Whitaker (ed.), Voting the Gender Gap. Chicago: University of Illinois Press, pp. 141-169; Campbell, Rosie. 2012. 'What Do We Really Know About Women Voters? Gender, Elections and Public Opinion.' The Political Quarterly. 83(4): 703-710; Carroll, Susan J. 2014. 
'Voting Choices: How and Why the Gender Gap Matters.' In Susan J. Carroll and Richard L. Fox (eds.), Gender and Elections: Shaping the Future of American Politics. pp. 119-145.

13. Waylen, Georgina. 2007. Engendering Transitions; Oxford: Oxford University Press; Ni Aolain, Fionnuala and Eilish Rooney. 2007. 'Underenforcement and Intersectionality: Gendered Aspects of Transition for Women.' The International Journal for Transitional Justice. 1: 338-354; Hayes, Bernadette C. 2017. 'Religious Differences in Electoral Turnout among Women in Northern Ireland.'

14. The 2015 Northern Ireland Election Survey was a nationally representative post-election survey of adults aged 18 years or older conducted immediately after the May 2015 general election. Using face-to-face interviews and with a response rate of 68.3 per cent, the survey was carried out by Social Market Research and based on a random sample of 1,810 adults.

15. The Agreement stipulated that key decisions in the assembly would be taken on a cross-community basis: either parallel consent (a majority of those present and voting, including a majority of unionist and nationalist delegations present and voting) or a weighted majority (60 per cent of members present and voting including at least 40 per cent of each of the nationalist and unionist delegations present and voting). To facilitate these rules, members of the assembly were obliged to designate as nationalist, unionist, or other.

16. Taylor, Rupert. 2009. 'The Injustice of a Consocational Solution to the Northern Ireland Problem.' In Rupert Taylor (ed.), Consociational Theory: McGarry and O'Leary and the Northern Ireland Problem. London: Routledge, pp. 309-329; Racioppi, Linda and Katherine O’Sullivan See. 2006. 'Engendering Democratic Transition from Conflict: Women's Inclusion in Northern Ireland.' Comparative Politics. 38(2): 189-208, p. 203.

17. For example, whereas the DUP gained 68.5 per cent of the unionist bloc vote, as compared to 31.5 per cent for the UUP, in the 2017 Northern Ireland Assembly election, the equivalent figures for SF and the SDLP within the Nationalist bloc vote were 70.1 per cent and 29.9 per cent, respectively. 
18. The degree to which a similar convergence on the constitutional question maintenance of the union with Britain versus a united Ireland - has occurred is open to some debate. While Mitchell et al (2009) and Garry (2009) point to the lack of movement, particularly within the DUP and the Protestant community more generally in terms of their wish to maintain the union with Britain, Garry (2009) also notes declining levels of support for a united Ireland within the nationalist community and an increasing endorsement for devolved government by both communities - unionist and nationalist - since the 2007 Assembly election. (see Mitchell et al., Extremist Outbidding in Ethnic Party Systems is Not Inevitable.'; Garry, John. 2009. 'Consociationalism and Its Critics: Evidence from the Historic Northern Ireland Assembly Election 2007.' Electoral Studies. 28(3): 458-466.

19. Mitchell, Paul, Evans, Geoffrey and Brendan O’Leary. 2001. 'Northern Ireland: Flanking Extremists Bite the Moderates and Emerge in Their Clothes.' Parliamentary Affairs. 54(4): 725-742; Mitchell et al., 'Extremist Outbidding in Ethnic Party Systems is Not Inevitable.'

20. McEvoy, Joanne. 2007. 'The Northern Ireland Assembly Election 2007.' Irish Political Studies. 22(3): 367-381; Garry, 'Consociationalism and its Critics.'; Matthews, Neil. 2011. 'The Northern Ireland Assembly Election 2011.' Irish Political Studies. 27(2): 341-358; Tonge, Jonathan and Jocelyn Evans. 2015. 'Another Communal Headcount: The Election in Northern Ireland.' In Andrew Geddes and Jonathan Tonge (eds.), Britain Votes 2015. Oxford: Oxford University Press, pp. 117132.

21. Hayes, Bernadette C. and Ian McAllister. 2013. Conflict to Peace: Politics and Society in Northern Ireland Over Half a Century. Manchester: Manchester University Press.

22. Set up in November 2012 when Arlene Foster (First Minister and leader of the DUP) was the Minister for Enterprise, the Renewable Heat Initiative (RHI) encouraged the installation of costly eco-friendly heating systems by paying a tariff over a twenty year period. Unlike the rest of the United Kingdom no cap was put on the money that could be claimed and it is estimated that it could cost Northern Ireland over four hundred million pounds. 
23. Brown and Ni Aolain, 'Through the Looking Glass.'

24. Galligan, 'Gender and Politics in Northern Ireland.' p. 419.

25. Kennedy et al. 'Challenging Identity Challenging Identity Hierarchies: Gender and Consociational Power-Sharing.'; Hayes, Bernadette C. and John Nagle. 2016. 'Ethnonationalism and Attitudes Towards Gay and Lesbian Rights in Northern Ireland.' Nations and Nationalism. 22(1): 20-41.

26. Galligan,. 'Gender and Politics in Northern Ireland.'; Matthews, Neil. 2014. 'Gendered Candidate Selection and the Representation of Women in Northern Ireland.' Parliamentary Affairs. 67(3): 617-646; Braniff, Maire and Sophie A. Whiting. 2015. “"There's Just No Point in Having a Token Woman": Gender and Representation in the Democratic Unionist Party in Post-Agreement Northern Ireland.' Parliamentary Affairs. 69(1): 93-114.

27. Braniff and Whiting, 'There's Just No Point in Having a Token Woman.'

28. A total of 27 female members were elected to the Assembly in 2017, three fewer than in 2016. However, due to the decrease in the overall number of members 90 in 2017 as compared to 108 previously - it represents a larger proportion of members - 30 per cent as compared to 27.8 per cent - than in 2016.

29. Hayes, 'Religious Differences in Electoral Turnout.'

30. Galligan, 'Gender and Politics in Northern Ireland.'

31. The equivalent percentages among the Protestant and Catholic male population were 48 per cent and 50 per cent, respectively.

32. The equivalent percentages among the Protestant and Catholic male population were 40 per cent and 33 per cent, respectively.

33. A similar pattern emerged when the male population was considered. For example where 65 per cent of Protestant men claimed to like the DUP, 64 per cent of Catholic men held a similar view about SF. 
34. This pattern is again replicated when the views of Protestant and Catholic men are compared, although judgements about the effectiveness of the two main parties are somewhat higher in this instance. For example, whereas 74 per cent of men within the Protestant community as compared to 80 per cent men within the Catholic community perceived the DUP and SF as an effective voice for their respective community, when the communities were considered separately, 58 per cent of Protestant judged the DUP as effective whereas 74 per cent of Catholic men held an identical view concerning SF. 
Table 1: Religious Differences in Party Attachment Among Women

\begin{tabular}{lccc}
\hline & Catholic & $\begin{array}{c}\text { (Percentages) } \\
\text { Protestant }\end{array}$ & All \\
\hline & & & \\
Yes & 45.9 & 40.3 & 42.8 \\
Somewhat & 15.9 & 10.7 & 13.0 \\
No & 38.1 & 48.9 & 44.2 \\
(N) & $(320)$ & $(419)$ & $(739)$ \\
\hline
\end{tabular}

Question: Questions: Generally speaking do you think of yourself as a supporter of any political party? Do you think of yourself as closer to one party in Northern Ireland than to others?

Source: Northern Ireland General Election Survey, 2015. 
Table 2: The Religious Gap in Party Attachment, 1998-2015

\begin{tabular}{cccccc}
\hline & 1998 & 2001 & 2005 & 2010 & 2015 \\
\hline Women & -4 & +1 & -8 & +6 & +6 \\
\hline
\end{tabular}

Note: The religious gap is the percentage of Catholics minus the percentage of Protestants who think of themselves as a party supporter.

Sources: 1998, 2001, 2005 Northern Ireland Life and Times Survey; Northern Ireland Election Surveys, 2010, 2015. 
Table 3: Religious Differences in Attitudes Towards the Two Main Political Parties Among Women

\begin{tabular}{lccc}
\hline & Catholic & $\begin{array}{c}\text { (Percentages) } \\
\text { Protestant }\end{array}$ & All \\
\hline Like: & & & \\
DUP/SF & 66.4 & 61.3 & 63.4 \\
(DUP) & $(2.2)$ & $(60.6)$ & $(35.6)$ \\
$($ SF) & $(64.6)$ & $(3.5)$ & $(29.7)$ \\
[Base N] & {$[319]$} & {$[424]$} & {$[743]$} \\
Most effective voice: & & & \\
DUP/SF (unionist/nationalist) & & & \\
DUP (unionist) & 77.7 & 67.7 & 72.0 \\
SF (nationalist) & $(52.9)$ & $(51.7)$ & $(52.2)$ \\
{$[$ Base N] } & $(69.9)$ & $(54.8)$ & $(61.3)$ \\
& {$[327]$} & {$[431]$} & {$[758]$} \\
\hline
\end{tabular}

Questions: Please say how you feel about the following political parties;. Which party do you think has been the most effective voice for unionists in Northern Ireland? Which party do you think has been the most effective voice for nationalists in Northern Ireland?

Source: Northern Ireland General Election Survey, 2015. 
Table 4: Changing Levels in Perceptions Concerning the Effectiveness of Two Main Political Parties Among Women, 2010-2015

\begin{tabular}{lccc}
\hline & & (Percentages) & \\
& 2010 & 2015 & Change \\
\hline $\begin{array}{l}\text { Catholic: } \\
\text { DUP/SF - unionist/Nationalist }\end{array}$ & 62.0 & & \\
$\begin{array}{l}\text { (DUP - unionist)) } \\
\text { (SF - nationalist) }\end{array}$ & $(29.2)$ & $(52.9)$ & +16 \\
& $(58.8)$ & $(69.9)$ & $(+11)$ \\
Protestant: & & & \\
$\begin{array}{l}\text { DUP/SF - unionist/nationalist } \\
\text { (DUP - unionist) }\end{array}$ & 62.5 & 67.7 & +5 \\
(SF - nationalist) & $(45.8)$ & $(51.7)$ & $(+6)$ \\
& $(52.4)$ & $(54.8)$ & $(+3)$ \\
\hline
\end{tabular}

Source: Northern Ireland General Election Survey, 2010 and 2015. 
Table 5: Explaining the Religion Gap in Party Attachment Among Women (n=647)

\begin{tabular}{|c|c|c|c|c|c|c|}
\hline & \multicolumn{6}{|c|}{ (Regression Coefficients (OLS) } \\
\hline & \multicolumn{2}{|c|}{ Model 1} & \multicolumn{2}{|c|}{ Model 2} & \multicolumn{2}{|c|}{ Model 3} \\
\hline & $\mathrm{b}$ & $(\mathrm{SE})$ & $\mathrm{b}$ & (SE) & $\mathrm{b}$ & (SE) \\
\hline \multicolumn{7}{|l|}{ Control variables: } \\
\hline Marital status (single) & --- & --- & .02 & $(.05)$ & .04 & $(.04)$ \\
\hline Church attendance (regular) & --- & --- & .07 & $(.04)$ & .07 & $(.04)$ \\
\hline Age (years) & --- & --- & $.01 * *$ & $(.01)$ & $.01 * *$ & $(.01)$ \\
\hline \multicolumn{7}{|l|}{ Education: } \\
\hline Tertiary & --- & --- & .10 & $(.07)$ & .11 & $(.06)$ \\
\hline Secondary & --- & --- & .07 & $(.06)$ & .08 & $(.05)$ \\
\hline No qualification $^{\mathrm{a}}$ & --- & --- & --- & -- & --- & --- \\
\hline Labour active & & & -.02 & $(.04)$ & .01 & $(.04)$ \\
\hline Identity (British) & & & .08 & $(.06)$ & .05 & $(.05)$ \\
\hline \multicolumn{7}{|l|}{ Attitudes Towards Parties: } \\
\hline DUP/SF (like) & --- & --- & --- & --- & $.32 * *$ & $(.04)$ \\
\hline DUP/SF (effective voice) & --- & --- & --- & --- & $.16^{* *}$ & $(.04)$ \\
\hline \multicolumn{7}{|l|}{ Religion Effect: } \\
\hline Catholic & $.09 *$ & $(.04)$ & $.15^{*}$ & $(.06)$ & .07 & $(.05)$ \\
\hline Constant & $.466 * *$ & & .111 & & -.183 & \\
\hline R-Squared & .009 & & .045 & & .212 & \\
\hline
\end{tabular}

Note: The dependent variable is coded 0 (no attachment), 0.5 (some attachment) and 1 (supporter); Standard errors are in parentheses; a, omitted category of comparison; *, statistically significant at $\mathrm{p}<.05, * *, \mathrm{p}<.01$.

Source: Northern Ireland Election Survey, 2015. 
Table 6: Attitudes Toward the DUP and SF and Electoral Behaviour Among Women

\begin{tabular}{lcccc}
\hline & \multicolumn{2}{c}{$\begin{array}{c}\text { Protestant } \\
\text { DUP most effective voice }\end{array}$} & \multicolumn{2}{c}{ CF most effective voice } \\
\hline & Yes & No & Yes & No \\
\hline Vote & 65.8 & 44.1 & 77.9 & 53.7 \\
(N) & $(146)$ & $(90)$ & $(176)$ & $(51)$ \\
& & & & \\
Vote choice: & & & & \\
DUP & 83.2 & 17.5 & 0.6 & 0.0 \\
UUP & 3.8 & 42.5 & 0.6 & 0.0 \\
Alliance & 2.3 & 13.8 & 2.6 & 13.3 \\
SDLP & 0.8 & 1.3 & 20.5 & 62.2 \\
SF & 0.0 & 2.5 & 75.0 & 17.8 \\
Other & 9.9 & 22.5 & 0.6 & 6.7 \\
(N) & $(131)$ & $(80)$ & $(156)$ & $(45)$ \\
\hline
\end{tabular}

Questions: Did you manage to vote in the 2015 General (Westminster) election? Which party did you vote for in the 2015 General Election?

Source: Northern Ireland General Election Survey, 2015 